\title{
Pbx proteins display hexapeptide-dependent cooperative DNA binding with a subset of Hox Proteins
}

\author{
Ching-Pin Chang, ${ }^{1}$ Wei-Fang Shen, ${ }^{2}$ Sofia Rozenfeld, ${ }^{2}$ H. Jeffrey Lawrence, ${ }^{2}$ Corey Largman, ${ }^{2}$ and \\ Michael L. Cleary ${ }^{1,3}$ \\ ${ }^{1}$ Laboratory of Experimental Oncology, Department of Pathology, Stanford University Medical Center, Stanford, California \\ 94305 USA; $^{2}$ Department of Medicine, San Francisco Veterans Affairs Medical Center, and University of California, San \\ Francisco, California 94121 USA
}

\begin{abstract}
The human proto-oncogene PBX1 codes for a homolog of Drosophila extradenticle, a divergent homeo domain protein that modulates the developmental and DNA-binding specificity of select HOM proteins. We demonstrate that wild-type Pbx proteins and chimeric E2a-Pbx1 oncoproteins cooperatively bind a consensus DNA probe with HoxB4, B6, and B7 of the Antennapedia class of Hox/HOM proteins. Specificity of Hox-Pbx interactions was suggested by the inability of Pbx proteins to cooperatively bind the synthetic DNA target with HoxA10 or Drosophila even-skipped. Site-directed mutagenesis showed that the hexapeptide motif (IYPWMK) upstream of the Hox homeo domain was essential for HoxB6 and B7 to cooperatively bind DNA with Pbx proteins. Engraftment of the HoxB7 hexapeptide onto HoxA10 endowed it with robust cooperative properties, demonstrating a functional role for the highly conserved hexapeptide element as one of the molecular determinants delimiting Hox-Pbx cooperativity. The Pbx homeo domain was necessary but not sufficient for cooperativity, which required conserved amino acids carboxy-terminal of the homeo domain. These findings demonstrate that interactions between Hox and Pbx proteins modulate their DNA-binding properties, suggesting that $\mathrm{Pbx}$ and Hox proteins act in parallel as heterotypic complexes to regulate expression of specific subordinate genes.
\end{abstract}

[Key Words: $\mathrm{Pbx}$; Hox; E2a-Pbxl; homeo domain proteins; proto-oncogene]

Received December 15, 1994; revised version accepted February 17, 1995.

Hox proteins are members of a large family of vertebrate transcription factors that share a similar DNA-binding motif known as the homeo domain (Scott et al. 1989). Hox proteins have many features in common with Drosophila homeotic selector (HOM) proteins including primary sequence, chromosomal organization of their respective genes, and regionally and developmentally restricted expression profiles (Akam 1989; McGinnis and Krumlauf 1992). Some Hox proteins have also been shown to function similarly in vivo to their Drosophila counterparts. For both Hox and HOM proteins, the homeo domain has been shown to mediate DNA binding in vitro and play an important role in the ability of these proteins to regulate transcription through specific target sequences (Desplan et al. 1988; Hoey and Levine 1988; Müller et al. 1988; Gehring et al. 1994a). The homeo domain has also been shown to make important contributions to the functional specificity of HOM proteins (Kuziora and McGinnis 1989, 1991; Dessain et al. 1992). However, recent data suggest that homeo domain proteins do not achieve their functional specificity on the

${ }^{3}$ Corresponding author. basis of DNA-protein interactions alone, as best illustrated by studies of fushi tarazu (ftz) showing that high affinity homeo domain-DNA interactions are neither sufficient nor necessary for its biological activity (Fitzpatrick et al. 1992; Ananthan et al. 1993; Schier and Gehring 1993).

Several studies suggest that the functional specificity of homeo domain proteins is determined by the combined effects of various individual interactions both within and outside of the homeo domain. Such interactions have been shown experimentally to influence the DNA-binding specificity of homeo domain proteins. For instance, combinatorial interactions between MCM1, MATal and MAT $\alpha 2$ determine the ability of al and $\alpha 2$ to recognize specific operators that mark genes regulating mating type in yeast (Johnson 1992). Homeo domain proteins may influence the DNA binding of nonhomeo domain proteins such as serum response factor (SRF), a mammalian protein with similarity to MCMl (Grueneberg et al. 1992). Protein-protein interactions may also influence the transcriptional properties of homeo domain proteins as shown for HoxD8 inhibition of HoxD9 activation, an effect dependent on contacts within helix 
1 of their homeo domains (Zappavigna et al. 1994). Studies of the POU and Oct 1 proteins (Stern et al. 1989; Ingraham et al. 1990; Voss et al. 1991; Treacy et al. 1992; Verrijzer et al. 1992; Xue et al. 1993), vHNF1 (Rey-Campos et al. 1991), and Paired class homeo proteins (Wilson et al. 1993) provide additional evidence that cooperative interactions play an important role in regulating their DNA-binding and functional properties.

Previous studies have identified a distinctive subfamily of atypical homeo domain proteins that are potential candidates for interactions with Hox/HOM proteins. These include the mammalian Pbx proteins, Drosophila extradenticle (exd), and Caenorhabditis elegans ceh-20 (Monica et al. 1991; Bürglin and Ruvkun 1992; Rauskolb et al. 1993), notable for their extensive similarities both within and outside of their homeo domains. Pbxl is a proto-oncogene that was originally discovered at the site of $t(1 ; 19)$ chromosomal translocations in pre-B cell acute leukemias (Kamps et al. 1990; Nourse et al. 1990). In Drosophila, genetic studies suggest that the $\mathrm{Pbx}$ homolog exd serves a unique role in segment identity through parallel interactions with homeotic selector proteins such as ultrabithorax (Ubx) and antennapedia (Antp) (Peifer and Weischaus 1990; Rauskolb and Weischaus 1994). Recent studies support this role by demonstrating cooperative interactions between exd and select HOM proteins (or engrailed) in DNA-binding assays (Chan et al. 1994; VanDijk and Murre 1994) and in a yeast two-hybrid system (Johnson et al. 1995). These studies are consistent with the thesis that biological specificity of homeotic selector proteins may be achieved, at least in part, through cooperative interactions that affect the manner in which they recognize and regulate downstream subordinate genes.

In this report we demonstrate that the DNA-binding affinity of $\mathrm{Pbx}$ proteins is markedly stimulated through interactions with a subset of Hox proteins under conditions where they demonstrate little or no inherent DNAbinding affinity alone. Cooperative DNA binding required the homeo domains and specific flanking amino acids in both the Hox and Pbx proteins. The conserved YPWM amino acid motif upstream of the homeo domain in many Hox proteins was essential for cooperativity, thereby establishing a role for this highly conserved element that may define a subset of Hox proteins capable of cooperative interactions with $\mathrm{Pbx}$ proteins. These studies support a model in which Pbx and Hox proteins act in parallel as heterotypic complexes to regulate expression of specific subordinate genes.

\section{Results}

Interaction of $P b x 1$ with $H o x B 7$ in a yeast two-hybrid assay

A search for proteins with the potential to interact with Pbx was initially conducted in yeast by use of a twohybrid assay (Harper et al. 1993). HoxB7 was selected for testing interactions with $\mathrm{Pbxl}$ as it is a cognate homolog of Ubx (Scott et al. 1989) that interacts with exd under comparable conditions (Johnson et al. 1995) and could be stably coexpressed with $\mathrm{Pbxl}$ in yeast cells. The homeo domain and flanking amino acids of HoxB7 were fused to the GAL4 DNA-binding domain in yeast vector pAS2 (construct pAS-ypHDB7) and various portions of $\mathrm{Pbxl}$ were fused to the GAL4 activation domain contained in pACT2 (Fig. 1). Yeast cells cotransformed with pACT$\mathrm{Pbxlb}$ and pAS-ypHDB7 showed activation of lacZ reporter gene expression under the control of the GAL4 UAS, whereas no $\beta$-gal activity was observed in cells transformed with each of the plasmids individually (Fig. 1; data not shown). The interaction between Pbxl and HoxB7 required the homeo domain of $\mathrm{Pbxl}$ as its deletion abrogated activation of $\beta$-gal expression (Fig. 1). A minimal portion of $\mathrm{Pbxl}$ consisting of 88 amino acids spanning the homeo domain and immediate carboxy-terminal flanking amino acids was sufficient for interaction with HoxB7. These observations suggested the potential for interaction between Pbxl and HoxB7 proteins mediated, at least in part, by the homeo domain of Pbxl.

\section{In vitro interaction of $\mathrm{Pbx}$ and Hox proteins is stimulated by the presence of $\mathrm{Pbx}$-binding site DNA}

The potential interaction of $\mathrm{Pbx} 1$ with HoxB7 was investigated further by immunoprecipitation analyses of in vitro-synthesized proteins. These experiments employed wild-type Pbxla with an epitope tag at its amino terminus. In vitro translated Pbxla-flag and HoxB7 were mixed and subjected to immunoprecipitation analysis with antibodies against the epitope tag. In parallel, the translocation-derived $\mathrm{E} 2 \mathrm{a}-\mathrm{Pbx}$ la fusion protein was also tested for potential interaction with HoxB7 with an antiE2a monoclonal. Precipitation of Pbx1a or E2a-Pbxla from in vitro translates showed little or no coprecipitated HoxB7 (Fig. 2). However, when an oligonucleotide (5'-CGAATTGATTGATGCACTAATTGGAG-3') containing consensus Hox (Pellerin et al. 1994) and Pbx (VanDijk et al. 1993; LeBrun and Cleary 1994; Lu et al.

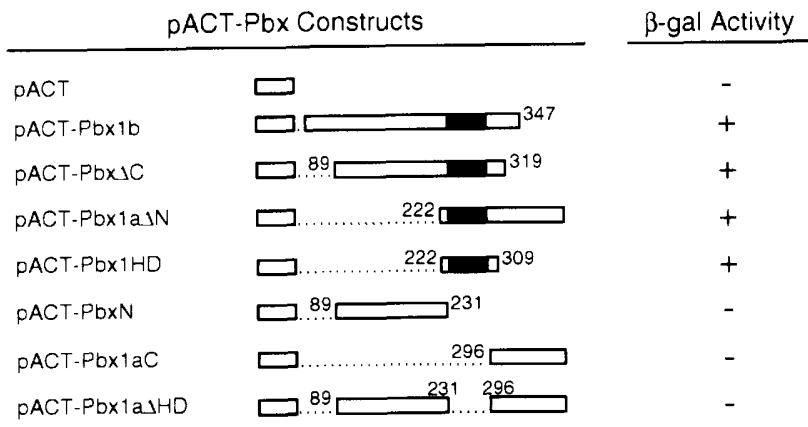

Figure 1. Interaction of $\mathrm{Pbxl}$ and $\mathrm{HoxB} 7$ in a yeast two-hybrid assay. Yeast was cotransformed with pAS-ypHDB7, and the indicated pACT plasmids, and then tested for activation of a lacZ reporter gene. $\beta$-Galactosidase ( $\beta$-gal) activity was determined by use of a filter blot assay in which conversion of the substrate (X-gal) was assessed after incubation for $2 \mathrm{hr}$ at $37^{\circ} \mathrm{C}$. Constructs showing no $\beta$-gal activity were also negative after $18 \mathrm{hr}$ at $37^{\circ} \mathrm{C}$. 


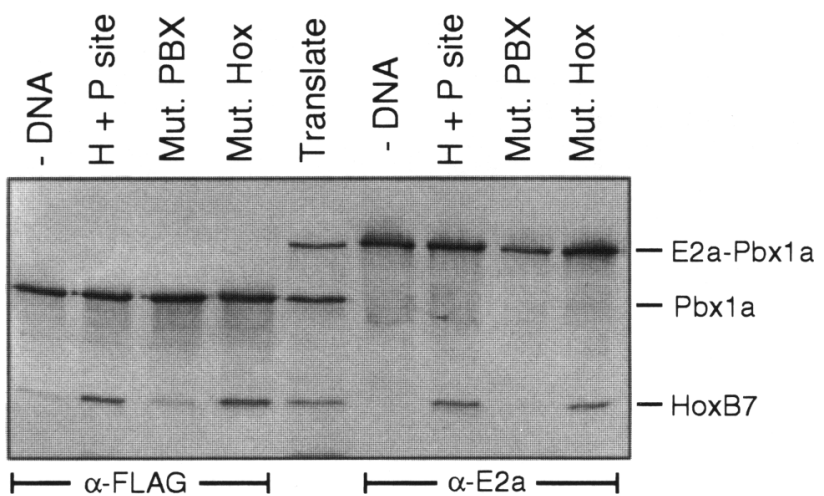

Figure 2. Coprecipitation of $\mathrm{Pbx}$ proteins with $\mathrm{HoxB} 7$ in the presence but not absence of DNA. In vitro-synthesized, radiolabeled proteins were mixed and allowed to associate in the presence or absence of the indicated oligonucleotide DNAs. Protein complexes were specifically precipitated with a monoclonal antibody against an epitope-tagged Pbxla or a monoclonal anti-E2a (Yae) antibody (denoted below gel lanes). Precipitated proteins were analyzed by SDS-PAGE and autoradiography. Labeling of lanes: (Translate) in vitro-translated proteins prior to precipitation; (-DNA) no input oligonucleotide DNA; $(\mathrm{H}+\mathrm{P}$ site) oligonucleotide with intact consensus $\mathrm{Hox}$ and $\mathrm{Pbx}$ sites; (Mut. PBX) oligonucleotide with mutant PBX site; (Mut. Hox) oligonucleotide with mutant Hox site.

1994) sites was added to the translated proteins, almost equimolar amounts of HoxB7 were coprecipitated with Pbxla or E2a-Pbxla. Mutation of the Pbx site but not the Hox site in the oligonucleotide reduced the amount of coprecipitated HoxB7 to residual levels (Fig. 2). Because a large molar excess (1000-fold) of binding-site DNA was present in the reactions, coprecipitation likely resulted from cooperative protein interactions and not simply independent binding of both proteins to the same DNA molecule. Taken together, the in vitro and yeast data were consistent with potential interactions between $\mathrm{Pbx}$ and HoxB7 that were enhanced in the presence of DNA containing an intact $\mathrm{Pbx}$ consensus binding site.

\section{Pbx proteins bind DNA cooperatively with $\mathrm{Hox} B 7$}

To determine the effect of $\mathrm{Pbx}$ and Hox interactions on their respective DNA-binding properties, electrophoretic mobility shift assays (EMSA) were performed. We used the oligonucleotide containing both Hox and Pbx consensus binding sites, which facilitated coprecipitation of a Hox-Pbx DNA complex. When this oligonucleotide was added to binding reactions containing in vitro-synthesized Pbxla or HoxB7 alone, no shifted complexes were observed under our EMSA conditions other than those corresponding to endogenous factors in the reticulocyte lysates (Fig. 3A). However, when both Pbxla and HoxB7 were incubated together with the probe, a unique complex was detected whose formation was dependent on increasing amounts of either Pbx or Hox protein (Fig. $3 \mathrm{~A}$, lanes 4-9|. Calculations based on the percent of shifted probe $(5 \%-10 \%)$ suggested that most of the input protein $\mid<0.3 \mathrm{ng}$ each) was bound to DNA. Thus, the observed DNA binding occurred at very low concentrations $(<0.5 \mathrm{nM})$ of $\mathrm{Pbx}$ and Hox proteins suggesting a highly specific interaction.

To assess the presence of both proteins in the shifted complex, supershift analyses were performed with specific antibodies. The complex formed by epitope-tagged Pbxla and wild-type HoxB7 was supershifted by a monoclonal antibody against the epitope tag (Fig. 3B, lane 2)

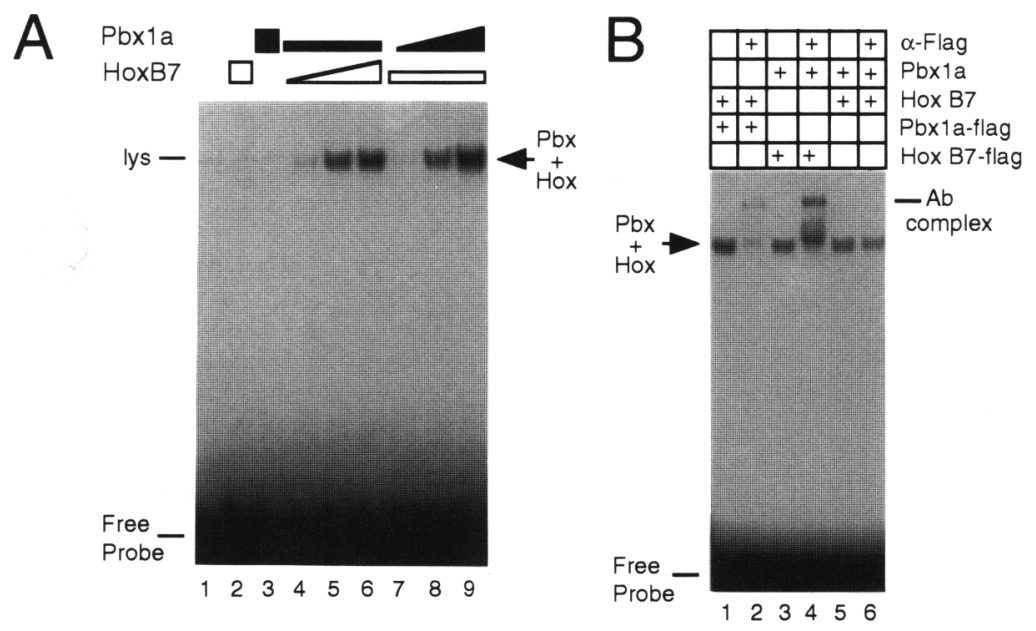

Figure 3. Pbx proteins bind DNA cooperatively with HoxB7. (A) EMSA demonstrating cooperative DNA binding by HoxB7 and Pbxla proteins. Various in vitro-translated proteins were incubated in DNA-binding reactions in the presence of radiolabeled probe and then subjected to EMSA. The oligonucleotide probe contained adjacent, consensus binding sites for Hox and Pbx proteins (Pellerin et al. 1994; LeBrun et al. 1994). The volumes of translates added to individual binding reactions were 4 $\mu l$ of unprogrammed lysate (lane 1 ); $3 \mu \mathrm{l}$ of HoxB7 $+1 \mu l$ of lysate (lane 2); $3 \mu l$ of Pbxla of +1 $\mu l$ lysate (lane 3 ); $1 \mu \mathrm{l}$ of HoxB7 $+1 \mu \mathrm{l}$ of Pbxla +2 $\mu l$ of lysate (lane 4); $2 \mu \mathrm{l}$ of HoxB7+1 $\mu \mathrm{l}$ of Pbxla $+1 \mu \mathrm{l}$ of lysate (lane 5); $3 \mu \mathrm{l}$ of $\mathrm{HoxB} 7+1 \mu \mathrm{l}$ of Pbxla (lane 6); $1 \mu \mathrm{l}$ of HoxB7 $+1 \mu \mathrm{l}$ of Pbxla +2 $\mu l$ of lysate (lane 7); $1 \mu \mathrm{l}$ of HoxB7 $+2 \mu \mathrm{l}$ of Pbxla $+1 \mu$ l of lysate (lane 8); $1 \mu \mathrm{l}$ of HoxB7 $+3 \mu \mathrm{l}$ of Pbxla (lane 9). (lys) Endogenous complexes present in the reticulocyte lysate that bind to the DNA probe; $(\mathrm{Hox}+\mathrm{Pbx})$ Complexes resulting from cooperative binding of Hox and Pbx proteins. $(B)$ Complexes resulting from cooperative DNA binding contain both Hox and Pbx proteins. Different combinations of in vitro-translated proteins (as indicated above the gel lanes) were incubated in DNA binding reactions and subjected to EMSA. For supershift analyses, monoclonal antibodies were added to binding reactions as indicated above the gel lanes. Binding reactions contained $2 \mu \mathrm{l}$ of each specifically programmed lysate. Supershifted and Hox/Pbx complexes are indicated respectively. (lys) Endogenous complexes present in the reticulocyte lysate. 
confirming the presence of Pbxla in the complex. The presence of HoxB7 was demonstrated by shifted migration with the anti-tag monoclonal antibody of a complex formed by coincubation of epitope-tagged HoxB7 and wild-type Pbxla (Fig. 3B, lane 4). Cooperative binding of a similar magnitude was also observed with $\mathrm{HoxB} 7$ and $\mathrm{Pbxlb}$, which differs from Pbxla in its carboxy-terminal portions, and with other $\mathrm{Pbx}$ family members $\mathrm{Pbx} 2$, $\mathrm{Pbx} 3 \mathrm{a}$, and $\mathrm{Pbx} 3 \mathrm{~b}$ (data not shown). These findings demonstrated that various wild-type $\mathrm{Pbx}$ proteins were able to bind DNA cooperatively as heteromeric complexes with HoxB7.

\section{Pbx1 cooperatively binds DNA with HoxB4 and HoxB6 but not HoxA10}

The spectrum of potential $\mathrm{Pbx} / \mathrm{Hox}$ interactions was addressed by determination of whether other Hox proteins could cooperatively bind DNA with Pbxl. These studies employed HoxA10, HoxB4, and HoxB6, which are members of paralog groups different from HoxB7. Similar to results with HoxB7, incubation of HoxB6 alone with the Hox/ $\mathrm{Pbx}$ combined-site probe resulted in no shifted complexes other than the endogenous lysate complex. Addition of increasing amounts of HoxB6 resulted in formation of a shifted complex similar but slightly slower in its migration to that observed for HoxB7-Pbxla (Fig. 4 , lanes $1-5)$. The shifted complex formed by co-incubation of HoxB6 and Pbxla contained both proteins as demonstrated by supershift analyses with specific antibodies (data not shown).

In contrast to HoxB6 and B7, incubation of HoxB4

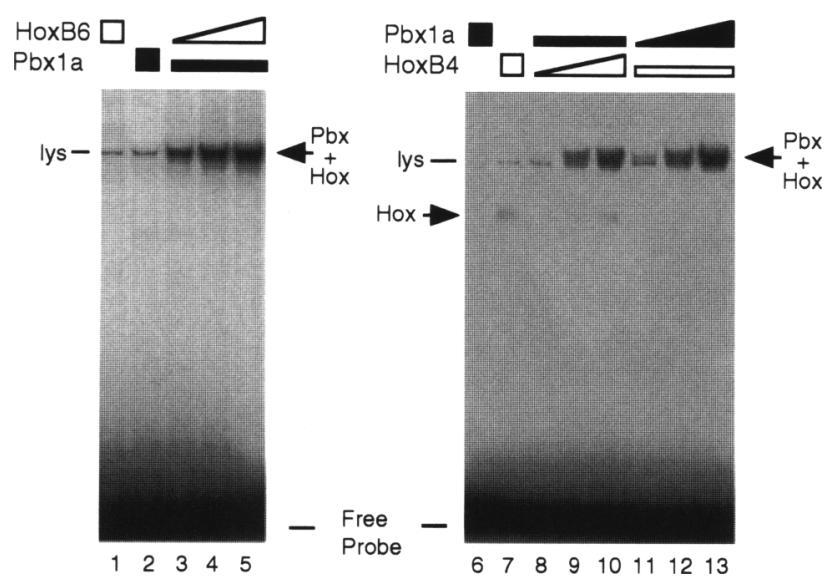

Figure 4. $\mathrm{Pbxl}$ cooperatively binds the consensus DNA probe with HoxB6 and HoxB4. In vitro-translated proteins were incubated in DNA-binding reactions in the presence of radiolabeled probe and then subjected to EMSA. The relative volumes of specifically programmed translates added to individual binding reactions are indicated above the gel lanes. Each binding reaction contained a $4-\mu$ l total volume of reticulocyte lysate (programmed + unprogrammed). (lys) Endogenous complexes present in the reticulocyte lysate that bind to the DNA probe. Hox alone (Hox) and cooperative Hox-Pbx (Hox + Pbx) DNAbound complexes are indicated, respectively.

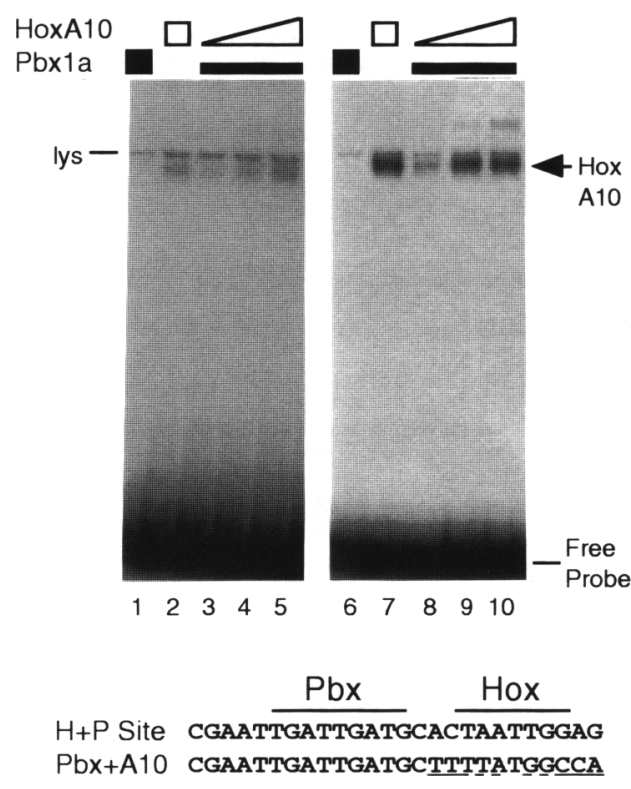

Figure 5. Pbxl does not cooperatively bind DNA with HoxA10. In vitro-translated proteins were incubated in DNAbinding reactions in the presence of radiolabeled probes and then subjected to EMSA. The relative volumes of specifically programmed translates $(4 \mu \mathrm{l}$ total) added to individual binding reactions are indicated above the gel lanes. Nucleotide sequences of the oligonucleotide probes are indicated below the autoradiograms; nucleotide differences in the $\mathrm{Pbx}+\mathrm{A} 10$ probe are underlined. (lys) Endogenous complexes present in the reticulocyte lysate that bind to the consensus DNA probe. Complex resulting from HoxAl0 alone binding to the probe is indicated at right.

with the combined-site probe showed a faint shifted complex in the absence of added Pbxla (Fig. 4, lane 7) indicating that HoxB4 alone bound the probe under these conditions, consistent with earlier studies on its inherently higher affinity for the consensus Hox site (Pellerin et al. 1994). In the presence of increasing amounts of Pbxla, a new, more abundant, complex was observed, whose migration was slower than that observed with HoxB4 alone (Fig. 4, lanes 8-13). Enhanced formation of the HoxB4-Pbxla complex compared to the HoxB4 complex was consistent with a cooperative effect on DNA binding, and supershift analyses (data not shown) confirmed the presence of both proteins in the complex.

Analogous experiments with HoxA10 showed that it also bound weakly to the combined-site probe in the absence of $\mathrm{Pbxl}$ (Fig. 5, lane 2) but in this case only minimal amounts of a slower migrating complex were observed in the presence of Pbxl (Fig. 5, lanes 3-5). When DNA binding was assessed by use of an oligonucleotide containing an optimal site for Abd-B (Ekker et al. 1994), which is a homolog of HoxA10, increased binding of HoxA10 alone was observed (Fig. 5, lane 7), but again a slower migrating complex observed in the presence of Pbxla was considerably less abundant than the complex containing HoxA10 alone (Fig. 5, lanes 8-10). This con- 
trasted with the robust cooperative binding observed for HoxB4, B6, and B7 in the presence of Pbxla with either the Hox-Pbx (Figs. 3 and 4) or the AbdB-Pbx (data not shown/ probes. An element of specificity to Hox-Pbx cooperativity was also suggested by the inability of Pbxla to bind cooperatively to either DNA probe in the presence of Drosophila even-skipped (data not shown). A reversed orientation of the Hox and Pbx sites in the Hox$\mathrm{Pbx}$ probe yielded reduced but not complete loss of cooperativity (data not shown). These observations indicated that $\mathrm{Pbxl}$ varied in its ability to cooperatively bind the synthetic DNA target with this set of Hox proteins. Specificity could not be entirely accounted for by differences in the binding affinities of the Hox proteins for the DNA probe, suggesting that $\mathrm{Hox}-\mathrm{Pbx}$ protein-protein interactions were playing an important role in delimiting the observed cooperativity.

\section{Chimeric E2a-Pbx1 oncoproteins bind DNA cooperatively with Hox proteins}

Chimeric E2a-Pbxl oncoproteins result from fusion with the heterologous E2a protein following chromosomal translocations in pre-B cell leukemias (Kamps et al. 1990; Nourse et al. 1990). Because fusion with E2a occurs in a highly conserved amino-terminal portion of $\mathrm{Pbxl}$, we assessed whether chimeric E2a-Pbxl proteins retain their ability to bind DNA cooperatively with Hox proteins. Incubation of E2a-Pbxla with HoxB7 resulted in a shifted DNA-protein complex whose migration was slower than $\mathrm{Hox}-\mathrm{Pbx}$ complexes formed with wild-type $\mathrm{Pbx}$ (Fig. 6A, lanes 3-8); no complex was seen when E2a$\mathrm{Pbxla}$ alone was incubated with the probe under these conditions (Fig. 6A, lane 2). Similar results were obtained with E2a-Pbxla and HoxB4 and B6 (data not shown).

The presence of both $\mathrm{E} 2 \mathrm{a}-\mathrm{Pbx} 1$ and $\mathrm{HoxB} 7$ in the DNA-bound complex was confirmed by supershift analysis. A monoclonal antibody against E2a resulted in complete conversion to a slower migrating complex as did a monoclonal antibody directed against an epitope tag in HoxB7 (Fig. 6B, lanes 2,4). Thus, replacement of the amino-terminal region of Pbxla with E2a does not impair cooperative DNA binding with Hox B4, B6, or B7.

\section{Cooperative DNA binding requires an intact $\mathrm{Pbx}$ site}

To determine whether $\mathrm{Pbx}-\mathrm{Hox}$ cooperativity required the presence of both Hox and Pbx sites, mutant oligonucleotide probes (Fig. 7) were used for DNA binding and EMSA. These studies compared the relative cooperative DNA binding of Pbxla with HoxB4, B6, and B7, respectively on each oligonucleotide probe. Analyses employing a probe with a mutant $\mathrm{Pbx}$ site resulted in complete abrogation of DNA binding by each of the Hox-Pbx complexes (Fig. 7, lanes 2,5,8). In contrast, various mutations of the Hox site showed a reduction but not complete loss of cooperative complex formation (Fig. 7, lanes 3,6,9). Probes Mut1-Hox and Mut2-Hox (data not shown) gave similar results. Quantitation of the shifted bands showed that the reduction in cooperative binding was greater for

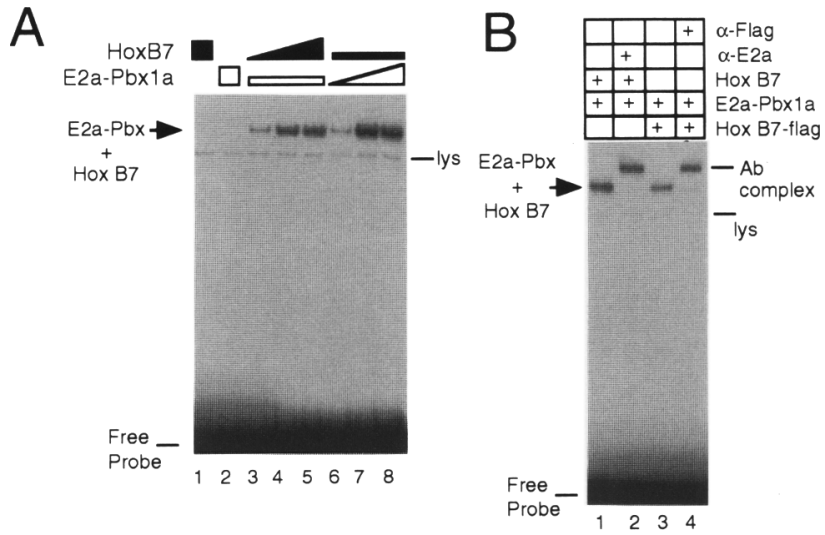

Figure 6. Chimeric E2a-Pbxl oncoproteins bind DNA cooperatively with HoxB7. (A) EMSA of in vitro-translated proteins. In vitro-translated proteins were incubated in DNA-binding reactions in the presence of radiolabeled probe and then subjected to EMSA. The relative volumes of specifically programmed translates ( $4 \mu \mathrm{l}$ total) added to individual binding reactions are indicated above the gel lanes. (lys) Endogenous complexes present in the reticulocyte lysate that bind to the DNA probe; (E2a$\mathrm{Pbx}+\mathrm{HoxB} 7)$ Complexes resulting from cooperative binding of $\mathrm{HoxB} 7$ and $\mathrm{E} 2 \mathrm{a}-\mathrm{Pbx}$ proteins. $(B)$ Complexes resulting from cooperative DNA binding contain both HoxB7 and E2a-Pbxl proteins. Different combinations of in vitro-translated proteins (4$\mu l$ total of specifically programmed lysate) added to DNA-binding reactions are indicated above the gel lanes. For supershift analyses, monoclonal antibodies were added to binding reactions as indicated above the gel lanes. The E2a-Pbxl chimera was detected with an anti-E2a monoclonal antibody. FLAGtagged $\mathrm{HoxB} 7$ proteins were detected with a monoclonal directed against the epitope tag. Supershifted and E2a$\mathrm{Pbx} 1+\mathrm{HoxB} 7$ complexes are indicated, respectively. (lys) Endogenous complexes present in the reticulocyte lysate.

HoxB4 $(70-80 \%)$ compared to HoxB6 $(60-65 \%)$ or HoxB7 $(50-60 \%)$. These findings were consistent with immunoprecipitation analyses showing that coprecipitation of HoxB7 with Pbxla was dependent on an intact $\mathrm{Pbx} 1$ site but relatively insensitive to Hox site mutation (Fig. 2). The unexpected observation that mutation of the Hox site resulted in only partial reduction in cooperativity compared with mutation of the $\mathrm{Pbx}$ site would appear to suggest that $\mathrm{Pbx}$ contributed most of the specificity of DNA binding on the synthetic site used for these studies. However, we cannot rule out the possibility that as part of a cooperative complex, Hox proteins may partially bind within the $\mathrm{Pbx}$ consensus site. Our findings demonstrate the importance of the consensus $\mathrm{Pbx}$ site for cooperativity but suggest that further analyses are necessary to fully define the optimal sequence requirements for cooperative binding.

The homeo domain and conserved flanking amino acids of Pbx1 mediate cooperative DNA binding with Hox proteins

To determine which portions of $\mathrm{Pbx}$ were required for cooperative DNA binding, deleted versions of Pbxla (Fig. 


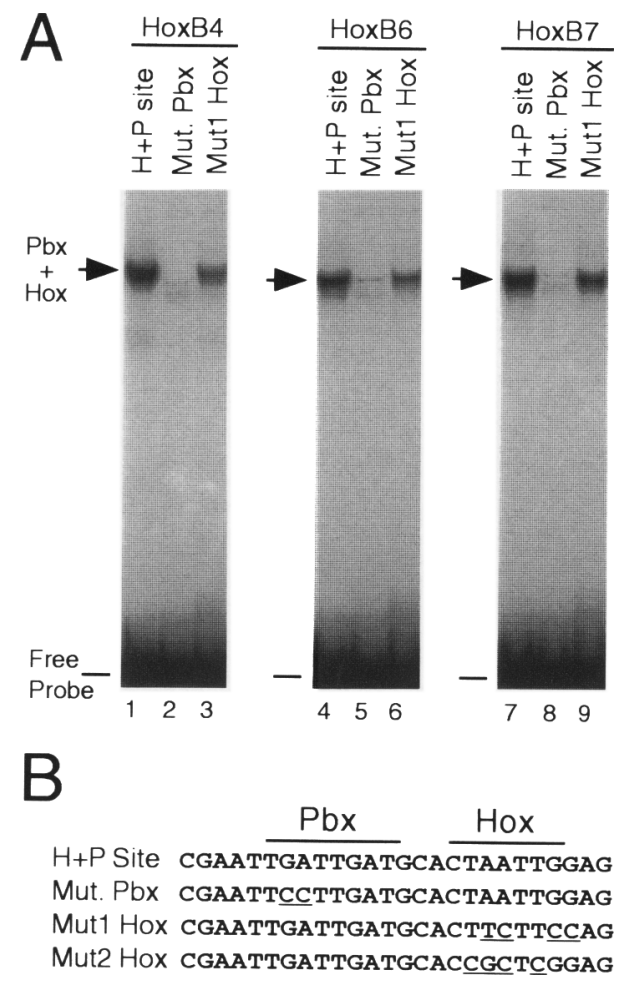

Figure 7. The $\mathrm{Pbx}$ site is required for cooperative DNA binding. (A) EMSA with mutant DNA probes. In vitro-translated proteins were incubated in DNA binding reactions in the presence of radiolabeled probe and then subjected to EMSA. Specifically programmed lysates $(4 \mu 1)$ and DNA probes added to individual binding reactions are indicated above the respective gel lanes. A second endogenous lysate band that is usually obscured by $\mathrm{Pbx}-\mathrm{Hox}$ complexes appears more prominent in lanes with the Mut. Pbx probe. $(B)$ Sequences of oligonucleotides used for EMSA. The consensus Hox and Pbx sites are indicated above the aligned sequences. Mutant nucleotides that deviate from the consensus are underlined.
8A) were used in binding reactions and analyzed by EMSA. Each of the mutant constructs was translated and analyzed by SDS-PAGE (Fig. 8B) to ensure that equivalent amounts of deleted $\mathrm{Pbx}$ proteins were added to the individual binding reactions. Data are only shown for cooperativity with HoxB7 although similar results were also obtained for HoxB4 and B6. A requirement for the $\mathrm{Pbx} 1$ homeo domain was demonstrated by the inability of construct $\triangle \mathrm{HD}$ to cooperatively bind the probe with HoxB7 (Fig. 8C, lane 6). However, the homeo domain alone was not sufficient because a construct containing only the 64 amino acids spanning the $\mathrm{Pbx} 1$ homeo domain was incapable of cooperative binding (Fig. 8C, lane 5 ), suggesting that at least some of the flanking amino acids were necessary. Cooperative DNA binding by construct $\Delta \mathrm{N}$ but not $\Delta \mathrm{C}$ implicated $\mathrm{Pbx}$ amino acids downstream of the homeo domain (Fig. 8, lanes 2,4). Deletion of the $\mathrm{Pbx}$ carboxy-terminus with preservation of 25 amino acids flanking the homeo domain (construct $\Delta \mathrm{C}+25$ ) did not abrogate cooperativity (Fig. $8 \mathrm{C}$, lane 3 ) thereby localizing the required downstream amino acids to conserved residues immediately flanking the homeo domain. A minimal construct containing the homeo domain plus 15 downstream amino acids cooperatively bound DNA in the presence of HoxB7, B6, or B4 (Fig. 8B, lanes 9-11) and weakly bound DNA in their absence (lane 8). Interstitial deletion of 10 amino acids from the implicated downstream region significantly reduced cooperativity by Pbxla (Fig. 8C, lane 7). Taken together, these results show that the determinants for cooperative DNA binding with this subset of Hox proteins are contained in the $\mathrm{Pbxl}$ homeo domain and a limited number of highly conserved carboxy-terminal flanking amino acids.

The Hox homeo domain and conserved YPWM motif are required for cooperative binding with $\mathrm{Pbx}$ proteins

A similar approach was employed to determine the por-
Figure 8. The $\mathrm{Pbx}$ homeo domain $(\mathrm{HD})$ is necessary but not sufficient for cooperative DNA binding with Hox proteins. $(A) \mathrm{Pbxl}$ deletion mutants used for EMSA are shown schematically. Solid boxes indicate homeo domains. Numbers correspond to amino acid positions (Monica et al. $1991)$ at deletion end points. (B) EMSA of cooperative DNA binding by HoxB7 and mutant Pbx proteins. In vitro-translated proteins were incubated in DNA-binding reactions in the presence of radiolabeled probe and then subjected to EMSA. Specifically programmed translates $(2 \mu \mathrm{l}$ of Hox protein plus $2 \mu \mathrm{l}$ of $\mathrm{Pbx}$ mutant/ added to individual binding reactions are indicated above the gel lanes. (lys) Endogenous complexes present in the reticulocyte lysate that bind to the DNA probe. Complexes resulting from cooperative binding of Hox and $\mathrm{Pbx}$ proteins are indicated by brackets. $(C)$ SDS-PAGE of in vitro-synthesized proteins. Various constructs encoding mutant $\mathrm{Pbx}$ proteins were translated in vitro and the radiolabeled proteins analyzed by SDS-PAGE.
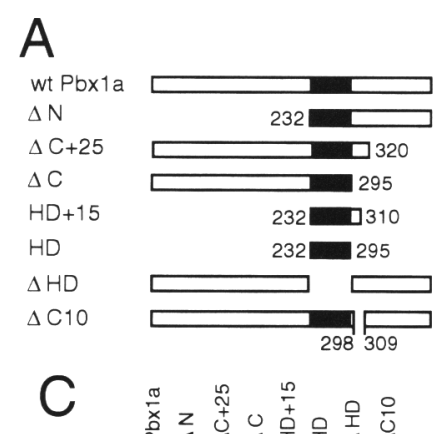

B
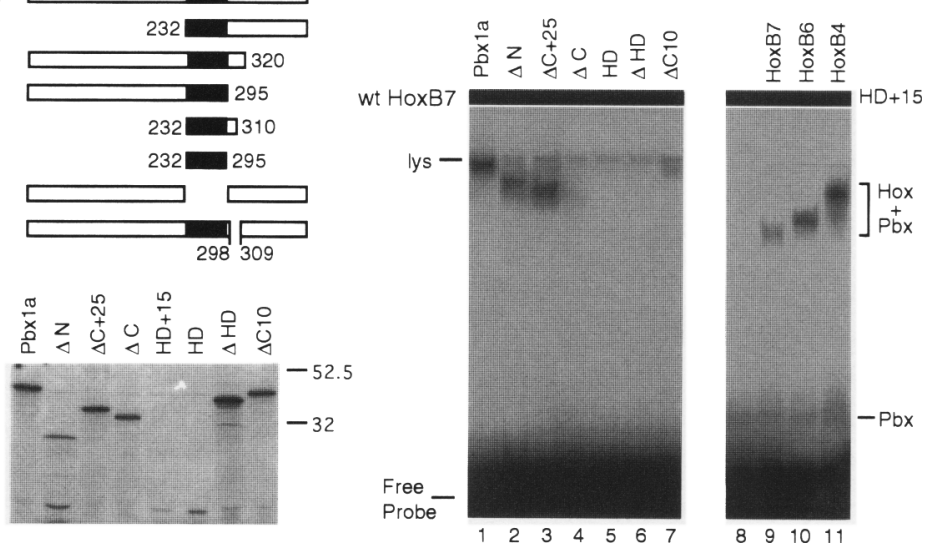
tions of HoxB7 required for cooperative DNA binding with Pbx. Various deleted HoxB7 proteins (Fig. 9A) were tested by EMSA for cooperative binding with wild-type Pbxla. A mutant lacking the carboxyl terminus and helix III of the homeo domain $(\Delta \mathrm{H} 3+\mathrm{C})$ was incapable of cooperativity with $\mathrm{Pbxla}$, suggesting that HoxB7 needed to bind DNA through its homeo domain, consistent with the observed partial dependence on an intact Hox site in the DNA probe. Specific carboxy- and amino-terminal truncations of HoxB7 that left the homeo domain intact did not affect cooperativity, thereby defining a minimal fragment (HD + YPWM) spanning amino acids 120-198 capable of cooperative DNA binding (Fig. 9C, lane 4). Deletion of 10 amino-terminal amino acids from this construct (HD-YPWM) resulted in loss of cooperativity in spite of the fact that this HoxB7 mutant could bind DNA weakly by itself in the presence (Fig. 9C, lane 5) or absence (data not shown) of Pbxla. A construct containing HD-YPWM plus the carboxy-terminal tail of HoxB7 also showed weak binding alone but no cooperativity (data not shown). These studies suggested that in addition to the HoxB7 homeo domain, additional flanking amino acids amino-terminal of the homeo domain were
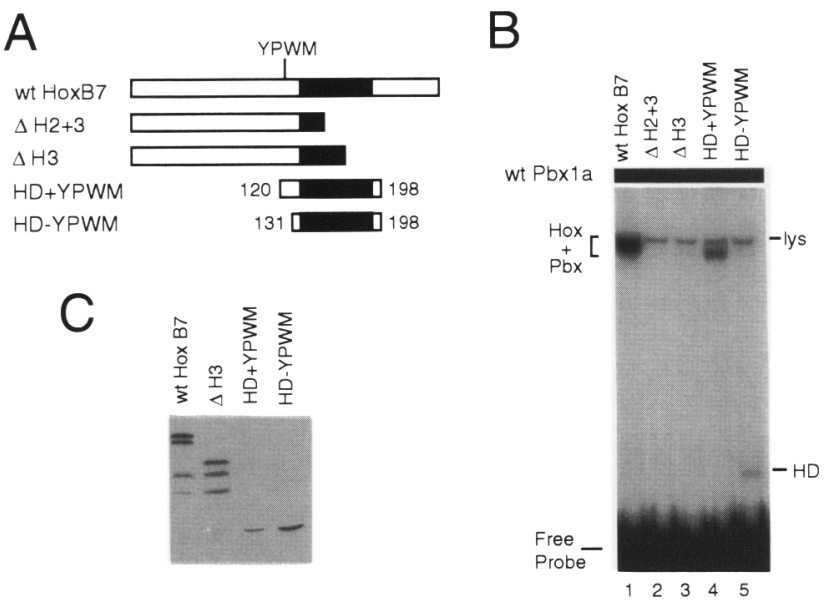

Figure 9. The Hox homeo domain and amino-terminal flanking amino acids are required for cooperative DNA binding with Pbx proteins. (A) HoxB7 deletion mutants used for EMSA are shown schematically. Solid regions indicate homeo domains. Numbers correspond to amino acid positions (Simeone et al. 1987) at deletion end points. (B) EMSA of cooperative DNA binding by $\mathrm{Pbxla}$ and mutant HoxB7 proteins. In vitro-translated proteins were incubated in DNA-binding reactions in the presence of radiolabeled probe and then subjected to EMSA. Specifically programmed translates $(2 \mu \mathrm{l}$ of Pbxla plus $2 \mu \mathrm{l}$ HoxB7 mutant) added to individual binding reactions are indicated above the gel lanes. (lys) Endogenous complexes present in the reticulocyte lysate that bind to the DNA probe. Complexes resulting from cooperative binding of $\mathrm{Hox}$ and $\mathrm{Pbx}$ proteins are indicated by brackets. (HD) Complex containing HoxB7 mutant HD-YPWM alone bound to the consensus DNA probe. $(C)$ SDSPAGE of in vitro-synthesized proteins. Various constructs encoding mutant HoxB7 proteins were translated in vitro and the radiolabeled proteins analyzed by SDS-PAGE.

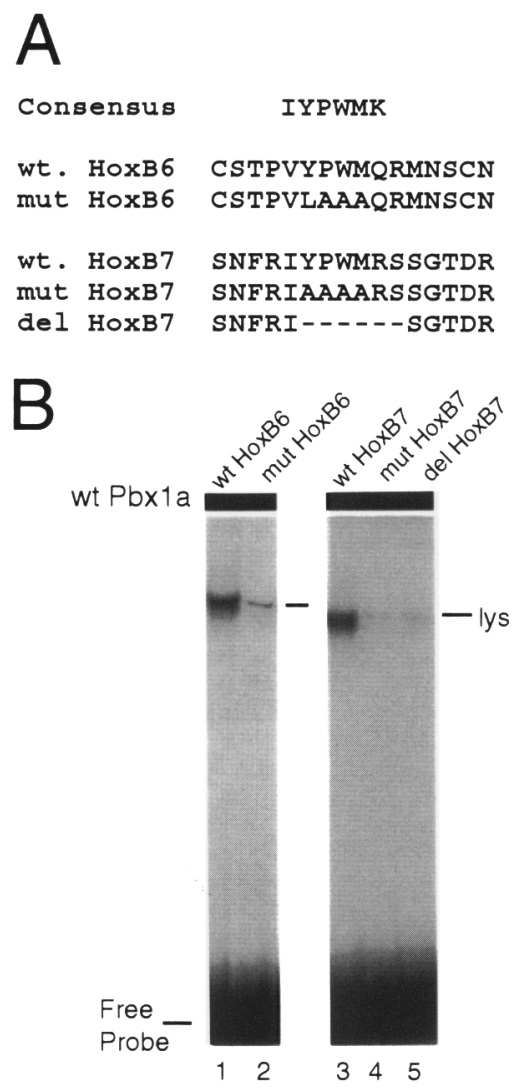

Figure 10. The conserved YPWM motif is necessary for cooperative DNA binding by HoxB6 and HoxB7. (A) Partial amino acid sequences of wild-type and mutant HoxB6 and B7 proteins showing amino acid alterations of the hexapeptide motifs. The consensus sequence is derived from analysis of the hexapeptide superclass of homeo domain proteins (Bürglin 1994). Amino acid residues are shown in single letter code. $(B)$ EMSA of cooperative DNA binding by Pbxla and mutant HoxB6 and HoxB7 proteins. In vitro-translated proteins were incubated in DNAbinding reactions in the presence of radiolabeled probe and then subjected to EMSA. Specifically programmed translates $(2 \mu)$ of Pbxla plus $2 \mu \mathrm{l}$ of Hox mutant) added to individual binding reactions are indicated above the gel lanes. (lys) Endogenous complexes present in the reticulocyte lysate that bind to the DNA probe.

required and that there was no requirement for residues carboxy-terminal to the homeo domain.

The region amino-terminal to the homeo domain of HoxB7 required for cooperativity contains the so-called hexapeptide motif that is highly conserved in a large subgroup of Hox/HOM proteins (Bürglin 1994; Gehring et al. 1994a). To test directly whether the hexapeptide motif was necessary for cooperative DNA binding, it was altered by site-directed mutagenesis in HoxB6 and B7 (Fig. 10A). A 6-amino-acid deletion spanning the motif in HoxB7 resulted in complete loss of cooperativity with Pbxla (Fig. 10B, lane 5). Missense mutation of four of the six residues of the motif in either HoxB7 or B6 also completely abrogated their cooperativity with Pbxla (Fig. 
10B, lanes 1-4). These data indicated that the hexapeptide motif plays a critical role in the observed Hox-Pbx cooperativity and likely accounts for the requirement of residues amino-terminal of the Hox homeo domain. Because HoxB7 proteins with hexapeptide mutations were incapable of binding DNA in the absence of Pbxla (data not shown), the YPWM motif does not have the characteristics of a negative regulatory element that inhibits HoxB7 binding on its own.

The role of the hexapeptide was tested further by determination of whether it was sufficient to enhance the ability of HoxA10 to cooperatively bind DNA with Pbxla. A mutant (hex-A10 in Fig. 11) was constructed in which amino acids 280-316 upstream of the HoxA10 homeo domain were replaced by 15 amino acids (120134) from HoxB7 spanning its hexapeptide. EMSA showed that both wild-type HoxA10 and hex-A10 mutant bound the DNA probe in the absence of Pbxla (Fig. 11 , lanes 1,5$)$. However, only hex-A10 displayed robust cooperativity in the presence of Pbxla (Fig. 11, lanes 2,6) comparable to that observed for HoxB7 (Fig. 11, lane 8). Most of hex-A10 was present in a complex with Pbxla in
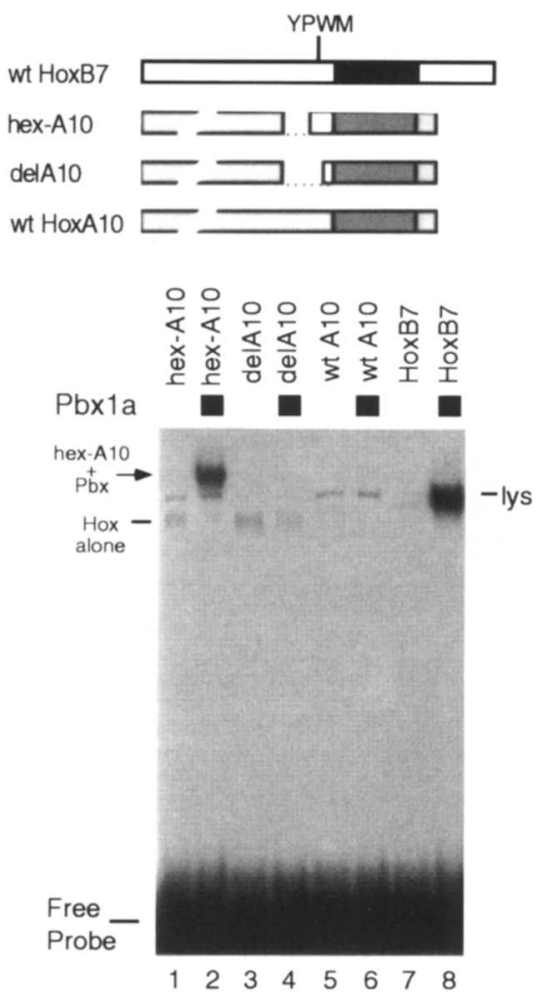

Figure 11. The hexapeptide motif is sufficient to confer cooperative DNA binding with $\mathrm{Pbx}$ proteins. Schematic representations of wild-type and mutant Hox proteins are shown at the top. The HoxB7 and A10 homeo domains are denoted by solid and shaded boxes, respectively. Open and hatched boxes denote HoxB7- and HoxA10-derived sequences, respectively. Dotted lines indicate deletions. (Bottom) EMSA of in vitro-translated proteins indicated above the gel lanes. Robust cooperativity with Pbxla was observed for the hex-Al0 mutant but not delAl0 or wild-type A10 proteins. contrast to wild-type HoxA10, which bound alone to the probe even in the presence of Pbxla. Cooperativity by mutant hex-A10 was directly attributable to the hexapeptide acquired from HoxB7 and not deletion of an inhibitory domain because a mutant HoxA10 with only a partial HoxB7 graft lacking the YPWM motif (del-A10) displayed no cooperativity (Fig. 11, lane 4). These data demonstrate that the hexapeptide motif is both necessary and sufficient for Hox proteins to cooperatively bind the synthetic probe with $\mathrm{Pbx}$ proteins.

\section{Discussion}

Evolutionary conservation of a molecular code that regulates $\mathrm{Hox}-\mathrm{Pbx}$ interactions

The studies reported here provide strong support for the thesis that $\mathrm{Pbx}$ proteins are selective cofactors for Hox proteins. Hox proteins have been assigned to paralog groups according to the degree of sequence conservation among their respective homeo domains (Gehring et al. 1994a). On this basis HoxB6 and B7 are in paralog groups that share the highest similarity with the Drosophila proteins Antp, Ubx, and Abd-A (the so-called Antp class). Both Ubx and Abd-A have recently been shown to cooperatively bind DNA with exd, the Drosophila homolog of Pbx (VanDijk and Murre 1994; Chan et al. 1994). Thus, in addition to structural conservation within their homeo domains, Hox/HOM proteins of the Antp class also demonstrate a conserved capacity to function as heterotypic DNA-binding complexes with $\mathrm{Pbx} /$ exd proteins. HoxB4 belongs to the Deformed class on the basis of sequence similarities inside and flanking the homeo domain. Because HoxB4 bound DNA cooperatively with $\mathrm{Pbxl}$, our data indicate that the capacity for cooperative interactions extends beyond the Antp class of homeo domain proteins to include other paralog groups. Cooperative interactions, however, were not observed with HoxAl0, which is a member of the Abd-B class, consistent with previous observations that exd does not cooperatively bind DNA with Abd-B (VanDijk and Murre 1994). Thus, Pbx/exd proteins appear to interact specifically with a select subset of homeo domain proteins.

Cooperative interactions between $\mathrm{Hox}$ and $\mathrm{Pbx}$ proteins appear to be determined at least in part by sequences outside of their respective homeo domains. For both HoxB6 and B7, amino acid residues immediately amino-terminal to their homeo domains were essential for cooperative DNA binding with Pbxl. Site-directed mutagenesis of the conserved hexapeptide motif in this region completely abrogated cooperative DNA binding with both HoxB6 and B7. The highly conserved hexapeptide motif defines a distinct superclass of homeo domain proteins that includes the Antp homologs HoxB6 and B7 as well as the Dfd family member HoxB4 and several other groups of homeo domain proteins outside of the HOM/Hox clusters (Bürglin 1994) whose representatives were not examined here. On the basis of our observations and those of others on Ubx (Johnson et al. 1995) it seems reasonable to propose that the hexapeptide motif 
constitutes a key molecular determinant of the ability of select homeo domain proteins to cooperatively interact with $\mathrm{Pbx} / \mathrm{exd}$ proteins.

Previous studies were unable to demonstrate cooperative DNA binding by Antp and exd (Chan et al. 1994), a surprising result given that Antp is a member of the hexapeptide superclass with a homeo domain that is highly conserved with HoxB7. However, the Antp construct employed by Chan et al. (1994) did not contain the hexapeptide motif. On the basis of our data, we predict that Antp and exd should cooperatively bind DNA, a prediction supported by genetic studies indicating that regulated expression of teashirt by Antp is dependent on exd function (Rauskolb and Weischaus 1994). It is also apparent that cooperativity with $\mathrm{Pbx} / \mathrm{exd}$ proteins is unlikely to be limited to the hexapeptide superfamily as engrailed, which lacks a hexapeptide motif, was shown to cooperatively bind DNA with exd (VanDijk and Murre 1994), although it has been noted that the engrailed EH2 motif contains residues that are somewhat reminiscent of the hexapeptide (Bürglin 1994). We cannot rule out the possibility that proteins such as HoxA10 may bind cooperatively with $\mathrm{Pbx} 1$ to different DNA targets as a result of interactions that do not require a hexapeptide motif. Additional studies are necessary to establish the complete spectrum of potential cooperative Hox-Pbx interactions but our studies suggest that the hexapeptide motif constitutes one critical component of a conserved molecular code governing at least some of these interactions.

Although previous studies suggested the importance of the Ubx carboxy-terminal tail for cooperativity with exd (Chan et al. 1994), the comparable region of HoxB7 was neither essential nor sufficient in our studies for cooperativity with Pbxla. A potential requirement for the carboxy-terminal tail of Ubx contrasts with the lack of sequence conservation in this region of Ubx, HoxB6, and $\mathrm{HoxB} 7$, which show similarity only in their homeo domains and hexapeptide motifs. However, the studies by Chan et al. (1994) employed Ubx constructs that lacked the conserved hexapeptide motif and were conducted at protein concentrations at least several hundred-fold over those employed by us. Weak cooperativity was previously observed for Ubx alone on a multisite probe and proposed to be mediated by sequences carboxy-terminal to the Ubx homeo domain (Beachy et al. 1993).

Our studies also define a domain within Pbx proteins that may regulate their DNA-binding properties and serve as a contact site for cooperative interactions with Hox proteins. This domain flanks the Pbxl homeo domain and is highly conserved in $\mathrm{Pbx}$ family members and their homologs exd and ceh-20 (Monica et al 1991; Bürglin and Ruvkun 1992; Flegel et al. 1993; Rauskolb et al. 1993|. By deletional mutagenesis we showed that removal of 10 conserved amino acids carboxy-terminal to the $\mathrm{Pbx} 1$ homeo domain severely compromised cooperative DNA binding, and a minimal construct containing the $\mathrm{Pbx}$ homeo domain demonstrated no cooperativity in the absence of downstream residues. These observations suggest that the downstream flanking amino acids play a critical role in stabilizing interaction of the $\mathrm{Pbx}$ homeo domain with DNA. Solution and crystal structures of homeo domains show that carboxyl flanking amino acids partially contribute to helix IV, an elongation of recognition helix III that may assume a flexibly disordered conformation in solution (Gehring et al. 1994b). We posit that Hox proteins may interact with the amino acids downstream of the $\mathrm{Pbx}$ homeo domain thereby inducing a conformational change in helix IV and flanking amino acids that stabilizes homeo domain binding to DNA. There is precedent for the role of carboxy-terminal amino acids in regulating heterotypic interactions between homeo domain proteins as reported previously for cooperative interactions between MEC-3 and Unc-86 (Xue et al. 1993).

Our observations open new doors for investigating how Hox proteins may achieve some of their functional specificity in spite of extensive similarities in their DNA binding homeo domains. For a subset of Hox proteins containing the hexapeptide motif this would occur through interactions with $\mathrm{Pbx}$ proteins. Although our initial observations of Hox-Pbx interactions support a model in which $\mathrm{Pbx}$ proteins serve accessory roles as parallel effectors of Hox activity they do not provide an answer to the question of how Hox proteins generate different outputs. Interactions with Pbx only allowed a distinction between the Hox4-7 and Hox10 paralog groups, which bind slightly different sequences. Furthermore, under our experimental conditions, $\mathrm{Pbx}$ appeared to contribute most of the binding specificity of the complex, an apparent weak means of achieving specificity given the general expression of $\mathrm{Pbx}$ versus Hox proteins (Monica et al. 1991). Clearly, additional studies are necessary to disect further the molecular code governing Hox $-\mathrm{Pbx}$ cooperativity and its potential contribution to specificity of Hox function. It remains to be determined whether DNA binding to physiologically relevant sites will reveal a greater role for Hox proteins in specificity of DNA binding within the context of Pbx cooperativity. It is also likely that additional combinatorial interactions with other transcription factors contribute to the functional specificity of Hox proteins.

The observed role of $\mathrm{Pbx}$ in cooperative binding in vitro shares some similarities with that of al, the homeo domain protein that interacts with $\alpha 2$ to repress genes involved in determination of yeast mating type (Johnson 1992). Most of the DNA-binding specificity derives from a1 which alone has no intrinsic DNA-binding activity. Contact of al, with the carboxy-terminal tail of $\alpha 2$, a low specificity DNA-binding protein by itself, creates a highly specific DNA-binding complex (Stark and Johnson 1994). Similar to al, full-length Pbxl has little or no intrinsic DNA binding ability even at high concentrations of $200 \mathrm{~nm}$ (C-P. Chang and M.L. Cleary, unpubl.) but is highly dependent on cooperative interactions to specifically bind its consensus DNA site. Like $\alpha 2$, the Hox proteins in our studies have relatively low intrinsic DNA-binding specificity (Pellerin et al. 1994), and amino acids outside of the Hox homeo domain appear to be 
critical for cooperative DNA binding with Pbxl. Thus, $\mathrm{Pbx}-\mathrm{Hox}$ cooperativity may adhere to the al $/ \alpha 2$ model, where two DNA-binding proteins with minimal intrinsic DNA binding ability can together create a specific DNA-binding complex. In spite of the similarities between $\mathrm{Pbx}-\mathrm{Hox}$ and al $-\alpha 2$ we have been unable to demonstrate cooperative binding of $\mathrm{Pbx}$ and Hox proteins on hsg operator sites (C-P. Chang and M.L. Cleary, unpubl.). These and other observations suggest that $\mathrm{Pbx}-\mathrm{Hox}$ heterodimers may prefer a configuration of half-sites different than al- $\alpha 2$, and additional studies are required to define optimal sequences for $\mathrm{Hox}-\mathrm{Pbx}$ cooperative DNA binding.

\section{Hox proteins may be essential cofactors for E2a-Pbx1 chimeric oncoproteins}

Our studies demonstrate that the cooperative effects of Hox proteins on $\mathrm{Pbx}$ DNA binding also extend to E2aPbxl chimeric oncoproteins that result from chromosomal translocations in acute pre-B cell leukemias. E2a$\mathrm{Pbxl}$ cooperatively bound the consensus $\mathrm{Pbx}$ site with Hox proteins under conditions that yielded no DNA binding by $\mathrm{E} 2 \mathrm{a}-\mathrm{Pbxl}$ alone. The portion of $\mathrm{Pbxl}$ required for cooperative DNA binding is comparable to the minimal portion of Pbxl that when fused to E2a is sufficient for transformation of NIH-3T3 cells (Monica et al. 1994). These findings suggest that $\mathrm{E} 2 \mathrm{a}-\mathrm{Pbxl}$ may be dependent on interactions with heterologous proteins for specific recognition of subordinate genes whose expression is responsible for oncogenesis. Although it is not clear from our studies which Hox proteins may cooperate with $\mathrm{E} 2 \mathrm{a}-\mathrm{Pbx} 1$ in $\mathrm{t}(1 ; 19)$-bearing leukemias, we note that the gene for HoxC4, which contains the YPWM motif, appears to be the major Hox gene expressed in lymphoid cells (Lawrence and Largman 1992; Lawrence et al. 1993). Additional studies characterizing endogenous lymphoid E2a-Pbxl complexes that bind the consensus $\mathrm{Pbx}$ site may help address this issue.

Although the Pbxl homeo domain and its flanking sequences are sufficient for transformation when fused to trans-activation elements from the E2a protein, the homeo domain, paradoxically, is not essential for transformation by E2a-Pbxl. Recent studies have shown that an $\mathrm{E} 2 \mathrm{a}-\mathrm{Pbx}{ }^{\Delta \mathrm{HD}}$ mutant transforms fibroblasts in vitro and induces malignant lymphomas in transgenic mice (Monica et al. 1994) that are indistinguishable from those induced by E2a-Pbx1 (Dedera et al. 1993). These findings suggested that $\mathrm{E} 2 \mathrm{a}-\mathrm{Pbx} 1$ may interact with cellular proteins that assist or mediate its effects on gene expression responsible for oncogenesis even in the absence of $\mathrm{Pbx}$ homeo domain-DNA interactions. A potential molecular explanation for transformation by the homeo domain-lacking mutant is suggested by the observed cooperativity between $\mathrm{Pbx}$ and Hox proteins. The deletion construct that maintained transforming activity lacked the homeo domain but preserved $\mathrm{Pbxl}$ amino acids outside the homeo domain that were shown in the present study to be necessary for cooperative DNA binding with $\mathrm{Hox}$ proteins. It is possible that the $\mathrm{E} 2 \mathrm{a}-\mathrm{Pbx}{ }^{\Delta \mathrm{HD}}$ mutant protein retains some of its ability to interact with a heterologous Hox protein forming a complex that can specifically bind a Hox DNA site and regulate the expression of critical subordinate genes analogous to activation of an engrailed-derived promoter by PRD and a $\mathrm{ftz}$ mutant lacking its homeo domain (Ananthan et al. 1993). Our inability to demonstrate a comparable interaction of Hox proteins with Pbx lacking its homeo domain may reflect limitations of the binding assay or the particular Hox proteins employed. Clearly, additional studies are necessary to further elucidate the role of Hox proteins in contributing to and perhaps defining the oncogenic effects of chimeric $\mathrm{Pbx}$ proteins. The studies reported here suggest a molecular model for understanding how wild-type and chimeric $\mathrm{Pbx}$ proteins may function in parallel with Hox proteins to regulate gene expression in normal and neoplastic cells.

\section{Materials and methods}

\section{DNA constructs}

In vitro expression clones for wild-type and chimeric $\mathrm{Pbx}$ proteins under control of the SP6 promoter have been described in previous studies (Nourse et al. 1990; Monica et al. 1991). Deletion constructs of $E 2 A-P B X 1$ have been reported elsewhere (Lebrun and Cleary 1994; Monica et al. 1994). For the current studies, additional deleted forms of $P B X 1$ and $H O X B 7$ cDNAs were constructed by use of standard cloning techniques and PCR. An epitope-tagged (FLAG) Pbxla was constructed by replacement of the nine amino-terminal amino acids with a synthetic oligonucleotide encoding the amino acids MDYKDDDDKSS. In vitro expression constructs for human HoxB4, HoxB6, HoxB7, and HoxA10 consisted of the respective human cDNAs (Simeone et al. 1987; Peverali et al. 1990; Shen et al. 1991) cloned downstream of the SP6 promoter. An epitopetagged form of HoxB7 consisted of 14 additional amino-terminal amino acids (MDYKDDDDKSRILA) fused in-frame to the HoxB7 initiating methionine. An epitope-tagged version of HoxB6 was constructed by addition of 20 amino acids (MDYKDDDDKSRILGSIEGRL) to its amino terminus. Grafting of the HoxB7 hexapeptide onto HoxA10 involved deletion of amino acids 280-316 of HoxAl0 and replacement of them with HoxB7 amino acids 120-134 (mutant hex-A10) or 131-134 (mutant delA10). An in vitro-expression construct for Drosophila evenskipped (pAR-EVE) in the pET3a vector has been described elsewhere (Hoey et al. 1988).

EMSAs

Various $\mathrm{Pbx}$ and Hox proteins were produced in vitro from SP6 expression plasmids by use of a coupled reticulocyte lysate system under conditions recommended by the supplier (Promega, Madison, Wis.). Hox and Pbx proteins were translated separately and then added to binding reactions. To ensure that approximately equal amounts of in vitro-translated proteins were present in binding reactions, parallel translation reactions were performed in the presence of $\left[{ }^{35} \mathrm{~S}\right]$ methionine, and labeled proteins were subjected to SDS-PAGE, quantitated on a PhosphorImager (Molecular Dynamics), and normalized for the number of methionine residues in each protein. DNA-binding reactions were performed at $4^{\circ} \mathrm{C}$ for $30 \mathrm{~min}$ and contained up to $4 \mu \mathrm{l}$ of reticulocyte lysate proteins $(<0.5 \mathrm{ng}$ of $\mathrm{Hox}$ or $\mathrm{Pbx})$ in a total volume of $15 \mu \mathrm{l}$ containing $2 \mu \mathrm{g}$ of poly[d(I-C)], $75 \mathrm{~mm} \mathrm{NaCl}, 1$ mM EDTA, $1 \mathrm{mM}$ DTT, $10 \mathrm{~mm}$ Tris- $\mathrm{HCl}(\mathrm{pH} 7.5), 6 \%$ glycerol, $2 \mu \mathrm{g} \mathrm{BSA}$, and 50,000 cpm of DNA probe (1 ng). Thirteen mi- 
troliters of the binding reactions was subjected to EMSA under conditions reported previously (Jacobs et al. 1993) with $6 \%$ polyacrylamide gels $(0.75 \mathrm{~mm}$ thickness $)$ in $0.25 \times$ TBE buffer. DNA probes $(50,000 \mathrm{cpm} /$ binding reaction) consisted of gel-purified, end-labeled, double-stranded oligonucleotides whose sequences are described in the text and Fig. legends. The combined-site DNA probe used for EMSA (5'-CGAATTGATTGATGCACTAATTGGAG-3') was designed to resemble yeast haploid-specific gene operator sequences based on similarites in the $\mathrm{Pbx}$ and al binding sites (TGATTGAT vs. TGATGTA, respectively) and assuming a tandem orientation (Goutte and Johnson 1994) of the Pbx and Hox proteins. DNA complexes were supershifted with commercially prepared antibodies directed against the FLAG epitope tag or a monoclonal directed against E2a (Jacobs et al. 1993). Antibodies (1 $\mu \mathrm{g})$ were added to DNA-binding reactions and incubated on ice for $2.5 \mathrm{hr}$ prior to addition of oligonucleotide probes.

\section{Immunoprecipitations}

In vitro-translated proteins in reticulocyte lysates $(10 \mu \mathrm{l}$ each of HoxB7 and Pbx translates/ were added to $180 \mu \mathrm{l}$ of $1 \times$ binding buffer $(10 \mathrm{~mm}$ Tris- $\mathrm{HCl}$ at $\mathrm{pH} 7.5,75 \mathrm{~mm} \mathrm{NaCl}, 1 \mathrm{~mm}$ EDTA, 1 mM DTT, $10 \%$ glycerol, 1\% BSA, $0.05 \%$ NP- $40,2 \mu \mathrm{g}$ of poly[(I$\mathrm{C})$ in the presence or absence of oligonucleotide DNA $(1 \mu \mathrm{g})$ and incubated overnight at $4^{\circ} \mathrm{C}$ in the presence of antibodies. For precipitation of Pbxla, an anti-flag monoclonal antibody $(1 \mu \mathrm{g} /$ $200 \mu \mathrm{l}$ ) was used with protein $\mathrm{G}$ sepharose beads. For precipitation of E2a-Pbxla, an anti-E2a monoclonal antibody (Jacobs et al. 1993/ cross-linked to sepharose beads was employed. Beads were washed 10 times with $1 \times$ binding buffer and precipitated proteins analyzed by SDS-PAGE.

\section{Yeast two-hybrid analysis}

Various fragments of $P B X 1$ cDNAs were cloned into pACT2 (Harper et al. 1993) in-frame with the GAL4 activation domain. A NarI-SacIl fragment of HOXB7 cDNA encoding amino acids 110-198 spanning the hexapeptide motif and homeo domain was cloned into pAS2 (Harper et al. 1993) in-frame with the GAL4 DNA-binding domain. Yeast strain Y190 was transformed to trp and leu prototrophy with the pACT-PBXl and pAS-HOXB7 constructs. Activation of the lac $Z$ reporter gene was determined by assessing $\beta$-gal activity with a filter lift assay (Breeden et al. 1985).

\section{Acknowledgments}

We gratefully acknowledge John Manak, Matthew Scott, Brad Johnson, and Mark Krasnow for helpful discussions and sharing of unpublished data. We thank Yakop Jacobs and Min Cui for many helpful discussions. We thank Phil Verzola for photographic assistance. This work was supported by a grant from the National Institutes of Health (CA42971) and by the Research Service of the Department of Veterans Affairs. M.L.C. is a scholar of the Leukemia Society of America.

The publication costs of this article were defrayed in part by payment of page charges. This article must therefore be hereby marked "advertisement" in accordance with 18 USC section 1734 solely to indicate this fact.

\section{References}

Akam, M. 1989. Hox and Hom: Homologous gene clusters in insects and vertebrates. Cell 57: 347-349.

Ananthan, J., R. Baler, D. Morrissey, J. Zuo, Y. Lan, M. Weir, and R. Voellmy. 1993. Synergistic activation of transcription is mediated by the $\mathrm{N}$-terminal domain of Drosophila fushi tarazu homeoprotein and can occur without DNA binding by the protein. Mol. Cell. Biol. 13: 1599-1609.

Beachy, P.A., J. Varkey, K.E. Young, D.P. von Kessler, B.I. Sun, and S.C. Ekker. 1993. Cooperative binding of an Ultrabithorax homeo domain protein to nearby and distant DNA sites. Mol. Cell. Biol. 13: 6941-6956.

Breeden, L. and K. Nasmyth. 1985. Regulation of the yeast HO gene. Cold Spring Harbor Symp. Quant. Biol. 50: 643-650.

Bürglin, T.R. 1994. A comprehensive classification of homeobox genes. Guidebook to the homeobox genes (ed. D. Duboule), pp. 27-41. Oxford University Press, Oxford, UK.

Bürglin, T.R. and G. Ruvkun. 1992. New motif in PBX genes. Nature Genet. 1: 319-320.

Chan, S-K., L. Jaffe, M. Capovilla, J. Botas, and R.S. Mann. 1994. The DNA binding specificity of Ultrabithorax is modulated by cooperative interactions with Extradenticle, another homeoprotein. Cell 78: 603-615.

Dedera, D.A., E.K. Waller, D.P. LeBrun, A. Sen-Majumbar, M.E. Stevens, G.S. Barsh, and M.L. Cleary. 1993. Chimeric homeobox gene $E 2 a-P b x 1$ induces proliferation, apoptosis, and malignant lymphomas in transgenic mice. Cell 74: 833-843.

Desplan, C., J. Theis, and P.H. O'Farrell. 1988. The sequence specificity of homeodomain-DNA interaction. Cell 54: 1081-1090.

Dessain, S., C.T. Gross, M.A. Kuziora, and W. McGinnis. 1992. Antp-type homeodomains have distinct DNA binding specificities that correlate with their different regulatory functions in embryos. EMBO I. 11: 991-1002.

Ekker, S.C., D.G. Jackson, D.P. von Kessler, B.I. Sun, K.E. Young, and P.A. Beachy. 1994. The degree of variation in DNA sequence recognition among four Drosophila homeotic proteins. EMBO J. 13: 3551-3560.

Fitzpatrick, V.D., A. Percival-Smith, C.J. Ingles, and H.M Krause. 1992. Homeodomain-independent activity of the fushi tarazu polypeptide in Drosophila embryos. Nature 356: 610-612.

Flegel, W.A., A.W. Singson, J.S. Margolis, A.G. Bang, J.W. Posakony, and C. Murre. 1993. Dpbx, a new homeobox gene closely related to the human proto-oncogene $p b x 1$ molecular structure and developmental expression. Mech. Dev. 41: 155-161.

Gehring, W.J., M. Affolter, and T. Bürglin. 1994a. Homeodomain proteins. Annu. Rev. Biochem. 63: 487-526.

Gehring, W.J., Y.Q. Qian, M. Billeter, K. Furukubo-Tokunaga, A.F. Schier, D. Resendez-Perez, M. Affolter, G. Otting, and K. Wüthrich. 1994b. Homeodomain-DNA recognition. Cell 78: 211-223.

Goutte, C. and A.D. Johnson. 1994. Recognition of a DNA operator by a dimer composed of two different homeodomain proteins. $E M B O$ I. 13: 1434-1442.

Grueneberg, D.A., S. Natesan, C. Alexander, and M.Z. Gilman. 1992. Human and Drosophila homeodomain proteins that enhance the DNA-binding activity of serum response factor. Science 257: 1089-1095.

Harper, J.W., G.R. Adami, N. Wei, K. Keyomarsi, and S.J. Elledge. 1993. The p21 Cdk-interacting protein Cipl is a potent inhibitor of G1-dependent kinases. Cell 75: 805-815.

Hoey, T. and M. Levine. 1988. Divergent homeobox proteins recognize similar DNA sequences in Drosophila. Nature 332: 858-861.

Hoey, T., R. Warrior, J. Manak, and M. Levine. 1988. DNAbinding activities of the Drosophila melanogaster evenskipped protein are mediated by its homeo domain and influenced by protein contact. Mol. Cell. Biol. 8: 4598-4607.

Ingraham, H.A., S.E. Flynn, J.W. Voss, V.R. Albert, M.S. Kapiloff, L. Wilson, and M.G. Rosenfeld. 1990. The POU-specific 
domain of Pit-1 is essential for sequence-specific, high affinity DNA binding and DNA-dependent Pit-1-Pit-1 interactions. Cell 61: 1021-1033.

Jacobs, Y., C. Vierra, and C. Nelson. 1993. E2A expression, nuclear localization, and in vivo formation of DNA- and nonDNA-binding species during B-cell development. Mol. Cell. Biol. 13: 7321-7333.

Johnson, A. 1992. A combinatorial regulatory circuit in budding yeast. In Transcriptional Regulation (ed. S.L. McKnight and K.R. Yamamotol, pp. 975-1006. Cold Spring Harbor Laboratory Press, Cold Spring Harbor, New York.

Johnson, F.B., E. Parker, and M.A. Krasnow. 1995. extradenticle protein is a selective cofactor for the Drosophila homeotics: Role of the homeodomain and YPWM motif in the interaction. Proc. Natl. Acad. Sci. (in press).

Kamps, M.P., C.M. Murre, X-H. Sun, and D. Baltimore. 1990. A new homeobox gene contributes the DNA binding domain of the $t(1 ; 19)$ translocation protein in pre-B ALL. Cell 60: $547-555$.

Kuziora, M.A. and W. McGinnis. 1989. A homeodomain substitution changes the regulatory specificity of the Deformed protein in Drosophila embryos. Cell 59: 563-571.

- 1991. Altering the regulatory targets of the Deformed protein in Drosophila embryos by substituting the Abdominal-B homeodomain. Mech. Dev. 33: 83-94.

Lawrence, H.J. and C. Largman. 1992. Homeobox genes in normal hematopoiesis and leukemia. Blood 80: 2445-2453.

Lawrence, H.J., K.M. Stage, C.H.E. Mathews, K. Detmer, R. Scibienski, M. MacKenzie, E. Migliaccio, E. Boncinelli, and C. Largman. 1993. Expression of HOX C homeobox genes in lymphoid cells. Cell Growth Diff. 4: 665-669.

LeBrun, D.L., and M.L. Cleary. 1994. Fusion with E2A alters the transcriptional properties of the homeodomain protein PBX1 in $t(1 ; 19)$ leukemias. Oncogene 9: 1641-1647.

Lu, Q., D.D. Wright, and M.P. Kamps. 1994. Fusion with E2A converts the $\mathrm{Pbxl}$ homeodomain protein into a constitutive transcriptional activator in human leukemias carrying the $t(1 ; 19)$ translocation. Mol. Cell. Biol. 14: 3938-3948.

McGinnis, W. and R. Krumlauf. 1992. Homeobox genes and axial patterning. Cell 68: 283-302.

Monica, K., N. Galili, J. Nourse, D. Saltman, and M.L. Cleary. 1991. PBX2 and $P B X 3$, new homeobox genes with extensive homology to the human proto-oncogene PBX1. Mol. Cell. Biol. 11: 6149-6157.

Monica, K., D.L. LeBrun, D.A. Dedera, R. Brown, and M.L. Cleary. 1994. Transformation properties of the E2a-Pbxl chimeric oncoprotein: Fusion with E2a is essential but the Pbxl homeodomain is dispensible. Mol. Cell. Biol. 14: 8304-8313.

Müller, M., M. Affoter, W. Leupin, G. Otting, K. Wüthrich, and W.J. Gehring. 1988. Isolation and sequence-specific DNA binding of the Antennapedia homeodomain. EMBO $I$. 7: 4299-4304.

Nourse, J., J.D. Mellentin, N. Galili, J. Wilkinson, E. Stanbridge, S.D. Smith, and M.L. Cleary. 1990. Chromosomal translocation $t(1 ; 19)$ results in synthesis of a homeobox fusion mRNA that codes for a potential chimeric transcription factor. Cell 60: $535-546$.

Peifer, M. and E. Wieschaus. 1990. Mutations in the Drosophila gene extradenticle affect the way specific homeo domain proteins regulate segmental identity. Genes \& Dev. 4: 12091223.

Pellerin, I., C. Schnabel, K.M. Catron, and C. Abate. 1994. Hox proteins have different affinities for a consensus DNA site that correlate with the positions of their genes on the hox cluster. Mol. Cell. Biol. 14: 4532-4545.

Peverali, F., M. D'Esposito, D. Acampora, G. Bunone, M. Negri,
A. Faicella, A. Stomaiuolo, M. Pannese, E. Migliaccio, A. Simeone, G. Della Valle, and E. Boncinelli. 1990. Expression of HOX homeogenes in human neuroblastoma cell culture lines. Differentiation 45: 61-69.

Rauskolb, C. and E. Weischaus. 1994. Coordinate regulation of downstream genes by extradenticle and the homeotic selector proteins. EMBO I. 13: 3561-3569.

Rauskolb, C., M. Peifer, and E. Weischaus. 1993. extradenticle, a regulator of homeotic gene activity, is a homolog of the homeobox-containing human proto-oncogene PBX1. Cell 74: 1101-1112.

Rey-Campos, J., T. Chouard, M. Yaniv, and S. Cereghini. 1991. vHNF1 is a homeoprotein that activates transcription and forms heterodimers with HNF1. EMBO $/$. 10: 1445-1457.

Schier, A.F., and W.J. Gehring. 1993. Functional specificity of the homeodomain protein fushi tarazu: The role of DNAbinding specificity in vivo. Proc. Natl. Acad. Sci. 90: 14501454.

Scott, M.P., J.W. Tamkun, and G.W. Hartzell. 1989. The structure and function of the homeodomain. Biochim. Biophys. Acta 989: 25-48.

Shen, W.F., K. Detmer, T.S. Simonitch-Eason, H.J. Lawrence, and C. Largman. 1991. Alternative splicing of the Hox 2.2 homeobox gene in human hematopoietic cells and murine embryonic and adult tissues. Nucleic Acids Res. 19: 539545 .

Simeone, A., F. Mavilio, D. Acampora, A. Giampaolo, A. Faiella, V. Zappavigna, M. D'Esposito, M. Pannese, G. Russo, E. Boncinelli, and C. Peschle. 1987. Two human homeobox genes, $\mathrm{Cl}$ and $\mathrm{C} 8$ : Structure analysis and expression in embryonic development. Proc. Natl. Acad. Sci. 84: 4914-4918.

Stark, M.R. and A.D. Johnson. 1994. Interaction between two homeodomain proteins is specified by a short C-terminal tail. Nature 371: 429-432.

Stern, S., M. Tanaka, and W. Herr. 1989. The Oct-1 homeodomain directs formation of a multiprotein-DNA complex with the HSV transactivator VP16. Nature 341: 624-630.

Treacy, M.N., L.I. Neilson, E.E. Turner, X. He, and M.G. Rosenfeld. 1992. Twin of I-POU: A two amino acid difference in the I-POU homeodomain distinguishes an activator from an inhibitor of transcription. Cell 68: 491-505.

VanDijk, M.A. and C. Murre. 1994. extradenticle raises the DNA binding specificity of homeotic selector gene products. Cell 78: 617-624.

VanDijk, M.A., P.M. Voorhoeve, and C. Murre. 1993. Pbxl is converted into a transcriptional activator upon acquiring the $\mathrm{N}$-terminal region of E2A in pre-B-cell acute lymphoblastoid leukemia. Proc Natl. Acad. Sci. 90: 6061-6065.

Verrijzer, C.P., J.A.W.M. van Oosterhout, and P.C. van der Vleit. 1992. The Oct-1 POU domain mediates interactions between Oct-1 and other POU proteins. Mol. Cell. Biol. 12: $542-551$

Voss, J.W., L. Wilson, and M.G. Rosenfeld. 1991. POU-domain proteins Pit-1 and Oct-1 interact to form a heteromeric complex and can cooperate to induce expression of the prolactin promoter. Genes \& Dev. 5: 1309-1320.

Wilson, D., G. Sheng, T. Lecuit, N. Dostatni, and C. Desplan. 1993. Cooperative dimerization of Paired class homeo domains on DNA. Genes \& Dev. 7: 2120-2134.

Xue, D., Y. Tu, and M. Chalfie. 1993. Cooperative interactions between the Caenorhabditis elegans homeoproteins UNC86 and MEC-3. Science 261: 1324-1328.

Zappavigna, V., D. Sartori, and F. Mavilio. 1994. Specificity of HOX protein function depends on DNA-protein and protein-protein interactions, both mediated by the homeo domain. Genes \& Dev. 8: 732-744. 


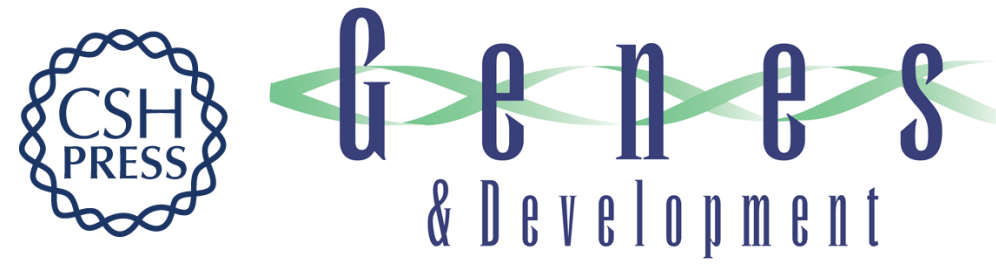

\section{Pbx proteins display hexapeptide-dependent cooperative DNA binding with a subset of Hox proteins.}

C P Chang, W F Shen, S Rozenfeld, et al.

Genes Dev. 1995, 9:

Access the most recent version at doi:10.1101/gad.9.6.663

References This article cites 53 articles, 21 of which can be accessed free at:

http://genesdev.cshlp.org/content/9/6/663.full.html\#ref-list-1

License

Email Alerting

Service

Receive free email alerts when new articles cite this article - sign up in the box at the top right corner of the article or click here.

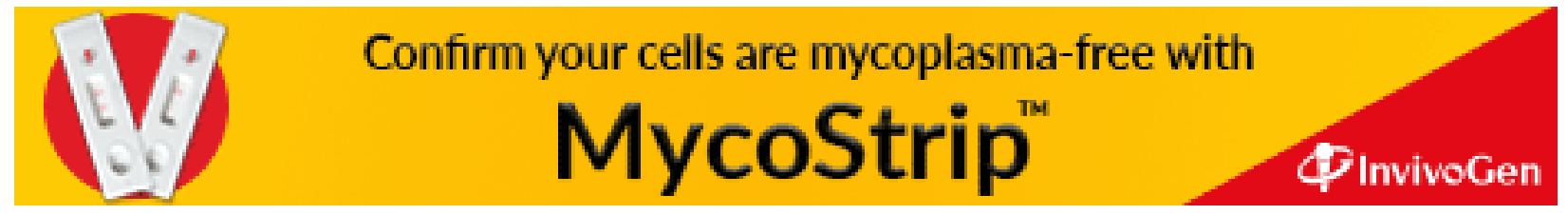

